\title{
DRAFTING OF REAL ESTATE INSTRUMENTS: THE PROBLEM FROM THE STANDPOINT OF THE REALTORS
}

\author{
Herbert U. Nelson*
}

Everyone who buys a piece of real estate or who has a piece of real estate for sale would eventually be affected by the outcome of suits which have been brought by local bar associations in the courts of a great many of the states. These suits seek to outlaw the ordinary business practice under which the real estate broker, who must be licensed by state authority in $3^{0}$ of the states, ${ }^{1}$ draws up ordinary instruments of agreement that are an integral part of his work. These suits aim to prevent him from even filling out forms of agreement which after long study by the most able men in the business of real estate, after scrutiny by the most capable lawyers in the field of real estate law, and after wide tests in use have been adopted as standard. Brought on the ground that selecting and filling out such instruments constitutes unauthorized practice of law, the suits attempt to make it legally necessary to employ a lawyer to draw the papers involved each time at practically every step of every real estate transaction. Within the last five years such suits have been brought by the local bar associations in at least seven states. In at least six states bar associations have sought legislation which would achieve the same objective.

\section{Public Welfare and the Development of Sound Real Estate Practice}

The question raised is one whose eventual determination must be on the basis of the public welfare involved. This cannot be said too strongly. It is the first plank in any discussion such as we are here entering. And considerations of grave public importance are involved. What is more, the crucial and underlying issue is one that has had almost no public attention. These suits threaten a loss of primary conditions for the development of sound real estate practice. The prohibition they seek would jacket the function of drafting real estate documents and isolate it from direct practical real estate business experience.

Loss in our whole economic progress must result if the process of arriving at business agreements is forced always to be one man removed from the process of

- B.A., x912, University of Minnesota. Executive Vice-President, National Association of Real Estate Boards. Secretary, American Institute of Real Estate Appraisers, and of the Institute of Real Estate Management. Editor, Freehold. Author of Real Estate Board Administration.

${ }^{1}$ And the District of Columbia and Hawaï. 
reducing these agreements to written form. Not the least such loss would be the loss of progress toward standard forms. As we develop a better understanding of real estate relationships, and of the contingencies that need to be provided for, we have come in recent years to standardize to a considerable extent the forms most commonly used in contracts to purchase, in leases, and the like. Standard forms tend to simplify business, eliminate confusion, avoid omissions. Any effort to block their use, if successful, would set business practices back a hundred years. Because this underlying issue is serious indeed, the National Association of Real Estate Boards, in a case recently before a Court of Appeals in Ohio, ${ }^{2}$ entered as amicus curiae to set forth some of the considerations involved that have a very general significance.

\section{Public Protection against Incompetent Drafting and Use of Real Estate Instruments}

Now two words to clear away questions not here at issue. The public must be protected against incompetent and unauthorized persons representing themselves fraudulently to be attorneys at law or setting themselves up as qualified to act for another in matters requiring training in the law. That goes without saying. That contention is not involved. Vigilance to prevent unauthorized practice of law has the wholehearted support of real estate men as of every business group. Further, the public must be protected against incompetents and incompetent guidance in the preparation and use of the documents that are the instruments of its real estate transactions. This latter proposition, accepted by both sides, has in it the crux of the whole decision. So well is it recognized in the business of real estate that real estate boards have long and consistently led the movement for such protection.

Legal instruments to be used in real estate transactions should, of course, be drawn, or scanned after they have been drawn, by someone having a thorough knowledge of the law involved. That is elementary for the protection of everybody in the transaction. But to accomplish what is intended it is just as important for everybody's protection that they be drawn with a full understanding of real estate conditions, and of the business contingencies that are likely to arise. What really matters is that the provisions contained be economically sound and prudent.

Members of the bar in their individual work and bar associations over our whole history have given immeasurable service in aiding the development of real estate's legal and business structure. We need that service constantly, and shall continue to need it. But if, as seems self-evident, protection in the use of real estate agreements must derive not only from knowledge of their legal effect but also from knowledge of their pertinency to the individual real estate situation involved, then it is by no means wise public policy or in the public interest to limit the right to draw every instrument in every transaction so as to give a monopoly to a group of men completely external to the business of real estate. This is not the road to the most

\footnotetext{
In the Matter of Unauthorized Practice of Law in Franklin County, Ohio (In re Gore), Court of Appeals, Franklin County, Ohio, No. 2755 (1938) Io OHIo BAR 5II. Brief presented by James M. Butler and Sol. Morton Isaac as attorneys for the Association with Nathan William MacChesney, general counsel of the Association, as counsel.
} 
efficient adjustment of individual agreements for the person of small or average means. Obviously, it is not the road to cutting costs. of home ownership or real estate ownership. Nor is it a condition that stimulates ingenuity to find ways that will the most helpfully meet the changing needs of changing times. I submit that it is not the road that will bring the least difficulties and the least likelihood of loss for the average business transaction. Without failing for a moment to realize the constructive value of what lawyers are doing in conjunction with real estate development, we may well fear that a monopoly of the function of developing business instruments by any group external to a business would tend to impose a rigidity of form and procedure that would be costly and destructive.

The National Association of Real Estate Boards holds no brief for the sporadic non-lawyer who may hold himself out to be qualified to draw up legal documents for others for a fee, but it does hold that a licensed real estate broker, not authorized to practice law, is competent, and should be permitted by law, to select, draft and complete preliminary contracts, simple deeds, simple leases, land contracts and mortgages, if he does so in the course of his business to consummate transactions in which he is inte'rested as agent or broker, and if he neither holds himself out to the public as one specially authorized to do these acts nor receives compensation for the preparation of these instruments.

\section{"Authorized" Practice of Law and Legal Instruments}

It may here be pointed out that if there be such a thing as the unauthorized practice of the law, there must be such a thing as the authorized practice of the law. Yet it is difficult to find any definition that fits the phrases. Lawyers and jurists have been satisfied with broad generalizations. Some of the state bar associations have frankly advised that there should be no attempt to formulate such definitions, and I believe I may say that the committee of the American Bar Association on this subject, headed by Mr. Stanley B. Houck, of Minneapolis, made it clear to my Association that the bar does not consider it possible or desirable that the so-called authorized practice of law shall be defined. In fairness, surely, there must come some attempt to establish frontiers or lines of demarcation.

Confusion in the use of the phrase "unauthorized practice of law" has its parallel in regard to the phrases "legal instruments" and "legal advice." What is a legal instrument? Does the mere fact that some business instruments are formal in language and employ some legal phraseology make them legal instruments? On the other hand, are not letters that commit clients and agents to specific agreements to be considered legal instruments? Unless we have a proper legal definition of what constitutes a legal instrument it is difficult to see how we can know what constitutes unauthorized practice of law. And such definition would have to divide not only business documents but much business correspondence into legal instruments and those which were not. Definition of authorized practice of the law might conceivably entail definition of "legal advice," which can be interpreted to mean advice 
purely on the wording of the laws and the interpretation of such wording, but which in our general careless use of the phrase stretches to cover advice which lawyers today give their clients. A strict definition would hardly include the very ordinary tendency of lawyers to enlarge their opinions to cover what, in view of the law, would constitute prudent conduct on the part of the client. It can hardly be questioned that much advice given by lawyers in our present common practice is essentially business advice.

Certainly it is not at all clear what constitutes the essential difference between ordinary business instruments and those affecting real estate and other forms of property. Receipts given by a clerk to a purchaser, especially in these modern days when standard forms of warranty are in common use, are in no way different in any essential legal principle from instruments given in connection with real estate, as the brief amicus curiae in the Ohio case to which I have already referred points out. The importance and consequences of legal phraseology are equal in both. A contract to buy any piece of merchandise on installment payments is essentially no different from a land contract. Indeed, as the brief points out, the business man of every kind faces simple legal problems continuously in his ordinary daily work. "He makes, draws, and completes contracts; he drafts bills of sale, bills of lading, notes, checks, and drafts; he collects accounts and compromises claims. For the most part, his legal problems as they affect himself and those with whom he deals have become so commonplace and stereotyped as to be a part of his ordinary equipment. He thinks of them not as legal problems but as a normal adjunct of his business." Only when the problems become complex (and the good business man knows instantly) he goes to his attorney for advice and the benefit of his learning. If we are to have the sweeping requirement that the bar associations have recently been seeking, and make the requirement consistent, the lawyer will draw up every bill of sale.

The real estate business, and indeed many another business, is here entering an unexplored country, one with no clear-cut conception or definitions which the layman can study, one where he is constantly moving at his own peril without a knowledge of what the law is. It is the feeling of the National Association of Real Estate Boards that if the Bar Association desires to clarify this issue it should submit appropriate legislation to the various state legislatures that will clearly define what constitutes the practice of law, so that all citizens may know their rights and obligations in this respect, and so that no one going about the ordinary conduct of his business affairs need be subjected to legislation that is not in the books as such but that exists by reason of judicial interpretation by the various courts.

\section{The Background of Real Estate Practicalities}

Let us go briefly into some of the practicalities of real estate practice to set the question as realistically as may be before us. Real estate transactions, and particularly the purchase of homes, are undertakings of a kind that the ordinary person may very 
well have occasion to enter into only once in his lifetime. Ignorance or incompetence in the choice of instrument or its drafting may in such a transaction be quite as fatal as downright fraudulent intent. But to effect the purposes of the parties buying, selling, leasing, or mortgaging real estate, the choosing and drafting of the instrument must be done in such a way as to take effective account of the practical purposes to be reached. It would fail in the very essential of their protection if from lack of knowledge of practical real estate situations, it failed to hit the business purpose as accurately as our present business knowledge will permit. It would fail to protect the parties to the agreement if clauses were either omitted or included in such a way as failed to provide for contingencies that business experience has taught us are, under the given circumstances, likely to arise.

An excellent if extreme example of contingencies which need to be provided for as accurately as possible through experienced acquaintance with the encompassing business conditions is found in the drawing of those leases of retail business property space in which rent is based on a percentage of the tenant's gross business. Another is the drawing of long-term leases for, let us say, properties in the central business sections of our great cities, leases that not infrequently have to cover all necessary exigencies in regard to a multi-million dollar property for, say, a period of 99 years. A good draftsman of a real estate instrument of such complexity is one who is familiar with all the relationships that are involved between buyer and seller, landlord and tenant. Clearly, competence in the draftsmanship of many such a document is not dependent upon knowledge of the law solely. One may perhaps be pardoned if he should raise the question of the competence of all attorneys, in such a case, to draft the documents and agreements incidental to the real estate business.

\section{Business Experience and Legal Acumen Can Be Mutually Helpful}

In ordinary actual practice a happy working relationship is blending business experience and legal acumen in formulating the structure of our real estate business agreements. For their own guidance members of the National Association of Real Estate Boards some years ago appointed a committee of their own laymen from various parts of the country to draft a long series of provisions found useful in the making of a long-term lease. They studied for the purpose provisions in practical and successful use which had had the benefit of expert legal counsel in the process of their evolution. They analyzed items which should be considered in creating, selling, or appraising long-term leases. Under forty-four heads the final compilation listed some $35^{\circ}$ items to be questioned in that process. Now many local real estate boards report that they are constantly in receipt of telephone calls and queries from attorneys concerning the provisions which such leases shall contain, in order that the documents may be sound and prudent ones. Real estate men can claim no monopoly of the recognition that, after all, it is the prudence and economic soundness of such documents and the understanding which they embody which is the important thing. 
Again for their own guidance, members of the National Association of Real Estate Boards have recently published a study of percentage leases with a section giving selected clauses assembled from many leases now in effect. Here were included clauses establishing rental, defining "sales and business transactions" upon which the rental is to be a percentage, giving warranty to tenant, providing that no partnership be created, providing for possible default or bankruptcy of the tenant, opening the possibilities of "equalization," a clause providing for recapture of the premises under stated conditions of deficiency in rent payments, giving the tenant opportunity to make up the deficiency and retain possession. But-significant for this discussion-in publication of such clauses careful note was given that the forms are not intended as a substitute for legal counsel, and that in adapting them for use in a new transaction they must be carefully checked both in order that they may conform with the varying state laws and with the varying local business conditions.

\section{Licensing and Ethical Requirements in Real Estate Business}

In the practice of the law, the requirements set up for admission to the bar, and the code of professional ethics of the American Bar Association are recognized instruments for protection of the public against incompetence on the one hand and unethical conduct on the other. In real estate business practice, a fair parallel exists. Laws requiring every real estate broker to be licensed by a state authority which is charged with the responsibility of shutting out those incompetent or unworthy of confidence already exist in all our most populous states. In something like half the states a written examination is required and in all states the trend is toward higher requirements. The development of standards of business practice is the central purpose of the National Association of Real Estate Boards, and of its member boards over the country. To this end the Association in I9I3 adopted a detailed code of business ethics and twenty-one years ago adopted the coined term Realtor to identify to the public persons bound, on penalty of expulsion from their real estate board, to observe that code, which has been kept a living expression of business conscience by revisions and additions. As in the last thirty years urban real estate use and value has become an increasingly complex subject, need of a rather high degree of technical preparation has become recognized, particularly in such branches of the business as appraisal and property management. Our specialized "Institutes" have concentrated on developing an understanding of the principles involved in these various branches, and some 70 colleges and universities have instituted real estate educational courses. At the initiative of the real estate business group a great National Real Estate Foundation is now in process of formation through which it is hoped to coordinate this whole movement of real estate research and real estate educational preparation to bring to public use in our real estate practice the immense body of facts and principles for which, for truly adequate public service, we will recognize that there is a need.

Two quotations from the Code of Ethics referred to are apt here: 
Article r2: In justice to those who place their interests in his hands, the Realtor should endeavor always to be informed regarding the law, proposed legislation, and other essential facts and public policies which affect these interests.

Article $3^{0}$ : In closing transactions, the Realtor should advise the use of legal counsel when the interest of any party to the transactions appears to require it; and in all cases he should exercise care in the preparation of documents so that they shall embody the exact agreements reached.

Not only is it the accepted good practice in the real estate field to employ legal counsel and to advise clients and customers to employ such counsel when needed; it is an emphatically necessary business policy to do so. The prestige and volume of a real estate man's business depends not a little upon his ability to inspire confidence that he can serve the public in its real estate wants with a minimum of controversy or legal entanglements. In this, it has been pointed out, he is not unlike the attorney whose ability to inspire a like confidence is not considered a minor asset. One's license to do a real estate business, no less than his business advancement, would be jeopardized were he to draw instruments which lead his clients and customers into untold difficulties.

It is an essential part of the real estate man's competence to know when the matter of drafting an instrument is so complex as to call for legal counsel, or to know when it is beyond his own experience. But it is obvious that if, on the verge of writing every apartment lease, or rent receipt, every contract to purchase, every listing of a property for sale, every commitment to loan, every mortgage and every deed, the transaction must halt till an attorney comes in and prepares the paper, there will entail an almost immeasurable waste in time, in cost, in difficulty of getting any meeting of minds, and there might well arise a socially undesirable reluctance on the part of people generally to undertake the ownership of a commodity so bound with red tape and tortuous circumambulations. And upon the real question of public policy involved, I believe we should have lessened rather than strengthened the likelihood of reaching in the average case the instrument that would work best and fit best the need of the situation. We shall have attorneys deluged with trivialities, but we shall have each individual user of real estate limited perforce to such legal experience in the field of real estate as he himself individually can afford to employ. We shall not have the leaven that is now at work bringing to the ordinary small transaction, through standard forms and related discussions, a city-wide or national real estate experience focused through employment of counsel who have given a lifetime of study to real estate law.

\section{Standard Forms and Practical Real Estate Experience}

As we come to a better understanding of real estate, in its complex present-day use, and better understand what contingencies need be provided for, we have come to standardize, to a great extent, the forms most commonly used. Forms so evolved include a standard office lease, a standard lease for loft properties, a standard apart- 
ment lease, a standard store lease, a standard extension of lease, a standard real estate management contract. These were evolved from examination, by business leaders representing every principal city in the country, of actual instruments that have been found most workable and successful. So formulated, they were scrutinized, thereupon, by an accepted authority on real estate law. Such standardized forms are made available only with the understanding that they must be checked for their adaptability to the varying state laws as well as the widely varying conditions of the localities or of the individual transactions.

It is our understanding that some of the local bar associations desire to do away altogether with all use of printed forms in the real estate business. In renting a large office building, for instance, some lawyers have contended that the use of a standard form of lease should be prohibited by the courts and that a lawyer should be engaged to write each individual lease for each individual office rented in such a building. Other lawyers have contended that in subdivisions, instead of using a printed contract or deed issued to lot buyers, there should be a lawyer employed to draft a separate instrument for each individual transaction in the subdivision. Obviously if printed forms, which have grown up through the experience of more than a hundred years, could not be used in such transactions and a great many others, a great deal of confusion as well as added cost would result.

Standardized procedure and standardized instruments and documents are as beneficial in the general business field as is the single price system in our stores. Any effort that would block such standardization and simplification is retrogressive in effect.

\section{Uniform Conveyancing Blanks in Wisconsin}

Wisconsin, under a statute which became effective January I, 1920, provides uniform conveyancing blanks for the general use of its citizens. ${ }^{3}$ Paul E. Stark, of Madison, president of the National Association of Real Estate Boards, reports that these are satisfactory and are generally used. The forms include warranty deeds, quit claim deeds, mortgages, land contracts, assignment of land contracts, assignment of real estate mortgages, partial release of mortgages, partial payment mortgage receipts, and satisfaction of real estate mortgages. Penalty for use of forms other than the uniform blanks is a $50 \%$ premium in registration fee. The suggestion for the Wisconsin uniform system of conveyancing blanks came originally from the Milwaukee office of the Register of Deeds, and drafting was done under the state group of registers of deeds. The movement was strongly supported from the beginning by the Milwaukee Real Estate Board, which appointed a committee to assist in drafting the forms.

A foreword to the published group Uniform Conveyancing Blanks of the State of Wisconsin (nos. I to 60 inclusive) recalls the first English parliamentary proposal for "some improvement in our method of transferring property,"-or, to go on with

\footnotetext{
${ }^{3}$ Wis. Stat. (1933), C. 235.
} 
its quotation from Oliver Cromwell, the parliament-prodder of his own time"enabling poor John Doe, who finds at present a terrible difficulty in doing it, to inform Richard Roe, 'I, John Doe do, in very fact, sell to Richard Roe, such and such a property,-according to the usual human meaning of the word sell: and it is hereby, let me again assure thee, indisputably SOLD to thee Richard, by me John,' which might be really an improvement." If we could rid all the documents incidental to real estate of useless legal verbiage and simplify them we should be doing much for the whole cause of real estate ownership and for the advantage of the whole body of our citizenry in their use of land and shelter.

\section{Business Must Be Free to Embody Its Experience in the Instruments It Uses}

"As the law of negotiable instruments grew from the Law Merchant, as the Uniform Sales Act is largely a codification of business practices, so business practices and policies must not be ignored in this comparatively new field," the brief filed by the National Association of Real Estate Boards in the Ohio case points out. This is especially true when it is considered how vitally general business may be affected by any decision on this subject. If, as conditions change, business is to develop instruments that are accurately and helpfully fitted to our social needs, it must be free to embody its experience as to what is sound practice in documents and agreements of its own making. Clearly much business law has thus crystallized. It would seem to be doubtul public policy to take away this freedom to develop its own forms of agreements, in accordance with the needs of the times, by imposing a compulsory obligation to employ lawyers to do such work, in other words, to make the drafting of real estate instruments a monopoly of the legal profession.

In the case of People $v$. Jersin, ${ }^{4}$ the Supreme Court of Colorado has recently given an opinion very pertinent to this whole issue. Written by Mr. Justice Young, the opinion points out the weakness of the premise on which the action was brought, namely, "that all acts done by a lawyer and constituting a practice of his profession, if performed by a layman, constitute a practice of law by the latter." In discussing the broad aspects of the case, the Justice says:

"Business is not the outgrowth of the practice of law. The practice of law is the outgrowth of business. ... What constitutes the emergencies and the exigencies of business in large measure always have depended, and always will depend, on the custom and practice of those who carry on the country's business, and within reasonable limits such customs and practices should, indeed must, be recognized."

74 P. (2d) 668, 670 (1937). 